\title{
Correction to: Supporting Community Participation for Sustainable Smart City Implementation in Indonesian Cities
}

\author{
Sushardjanti Felasari
}

\begin{abstract}
Correction to:
Chapter "Supporting Community Participation

for Sustainable Smart City Implementation in Indonesian

Cities" in: A. Rotaru (Ed.): Critical Thinking in the Sustainable

Rehabilitation and Risk Management of the Built Environment, SSGG, https://doi.org/10.1007/978-3-030-61118-7_38
\end{abstract}

In the original version of the book, the following belated correction has been incorporated: The name "Muhammad Sani Roychansyah" has been removed from Frontmatter, Backmatter and Chapter 38.

The book and the chapter have been updated with the change. 